\title{
EREBEA
}

Revista de Humanidades

y Ciencias Sociales

Núm. 1 (2011), pp. 41-56

ISSN: 0214-0691

\section{Preaching the Sacraments: Catechesis for the Laity or Education for the Clergy?}

\author{
Roger Andersson \\ Universidad de Estocolmo
}

Resumen

Es un estudio sobre una serie de quince cortos sermones (collationes) acerca de los sacramentos que fueron predicados por un fraile no identificado ('frater Ingemarus') en el contexto de las visitas realizadas por su arzobispo Birgerus Gregorii a la diócesis de Uppsala durante el invierno de 1376-77. Tras resumir brevemente el contenido de los sermones, el autor debate la cuestión de su audiencia, argumentando que las "collationes" no iban dirigidas sólo a los sacerdotes, sino también, a lo que parece, a todo el que se hallaba presente en las iglesias visitadas. Su evocadora imaginería sugiere que podían haber sido concebidos específicamente para los laicos, un auditorio necesitado no sólo de instrucción en los siete sacramentos sino también de impulso para beneficiarse de sus efectos.

Palabras Clave

Edad Media, Sermones, Predicación, Sacramentos, Visita.

Fecha de recepción: 12 de febrero de 2011 Fecha de aceptación: 1 de marzo de 2011

\section{Abstract}

This study investigates into a series of fifteen short sermons (collationes) on the Sacraments, preached by an unidentified friar ('frater Ingemarus') in connection with the visitations that his archbishop Birgerus Gregorii made in the diocese of Uppsala in the winter of 1376-77. The contents of the sermons are briefly summarized and the question of audience is discussed. The article argues that the collationes were not only directed to the priests but seemingly to all who were present in the churches visited by the bishop. The evocative imagery suggests that they may have been targeted specifically at lay people, an audience that needed not only instruction about the Seven Sacraments but also needed to be moved in their hearts to fully grasp their effects.

\section{KeYwORDS}

Middle Ages, Sermons, Prearching, Sacraments, Visitation. 

While the evidence for preaching in medieval Sweden to a large extent is based on the important legacy of sermon manuscripts from Vadstena Abbey, mother house of the Birgittine Order, sermon collections from other ecclesiastical institutions - both secular and regular - have also been preserved to our day. Not surprisingly, the most important of these contributions to the history of Swedish preaching in the Middle Ages, besides that of Vadstena, are the collections produced within the mendicant orders, and, of these, the most prominent, at least if one considers the number of preserved manuscripts, seem to be the Franciscan house in Stockholm and the Dominican house in Sigtuna. ${ }^{1}$

As a matter of fact, it may well be that the earliest attestation of actual preaching in medieval Sweden is the work of a mendicant friar.

In Uppsala University Library, MS C 5, fol. 26r, we read the following: 'Iste sunt collaciones quas fecit frater Ingemarus in visitacione domini archiepiscopi Vpsalensis, anno Christi 1376' ('These are the collations that friar Ingemar held in connection with the visitation of the archbishop of Uppsala in the year 1376'). Birger Gregersson (or Birgerus Gregorii, ca 1327-83), archbishop from 1366, is among the most well-known of medieval Swedish clergy. ${ }^{2}$ A series of fifteen collationes, all treating the Sacraments, occupy the next twenty folios. ${ }^{3}$ This codex

1 For an overview of the preaching at Vadstena see Roger Andersson and Stephan Borgehammar, 'The Preaching of the Birgittine Friars at Vadstena Abbey (ca 1380-1515)', Revue Mabillon. Nouvelle série 8 (t. 69, pp. 209-36): About twenty manuscripts from the library of the Dominicans in Sigtuna are extant; their emphasis is on French theology and scholastic preaching. Yet a few more extant codices - with more diversified contents - belonged to the Franciscans in Stockholm. See Monica Hedlund, 'Medeltida kyrko- och klosterbibliotek i Sverige', Helgerånet. Från mässböcker till munkepärmar (Stockholm: Riksarkivet \& Carlssons, 1993), pp. 25-36 (pp. 29-33).

2 See for example Svenskt biografiskt lexikon, t. IV (1924), pp. 424-27.

3 Mittelalterliche Handschriften der Universitätsbibliothek Uppsala. Katalog über die C-Sammlung, ed. by Margarete Andersson-Schmitt, Håkan Hallberg and Monica Hedlund, vol. 1-8. Acta Bibliothecae R. Universitatis Upsaliensis, vol. XXVI:1-8 (Stockholm: Almqvist \& Wiksell, 1988-95), vol. 1 (1988), pp. 60-62. Only one of these collationes (the fourteenth, fols 38r-39r) has been edited; see Aarno Maliniemi, De S. Henrico episcopo et martyre: Die mittelalterliche Literatur über den Apostel Finnlands. Finska Kyrkohistoriska Samfundets Handlingar, XLV (Helsinki: Finska Kyrkohistoriska Samfundet, 1942), pp. 19-22 (manuscript description) and 101-05 (edition). Even though these texts have not yet been subjected to any systematic analysis, they have attracted the attention of a number of church historians. In his study of the Swedish diocesan synod S. Kroon discusses a sermon delivered by Ingemar at the synod in Uppsala 1376, following immediately after the collationes in the same manuscript. See Sigurd Kroon, Det svenska prästmötet under medeltiden. 
in itself is not of mendicant origin. An owner's mark at the end indicates that it once belonged to the library of Vadstena Abbey, but the book is a miscellany, where quaterni written by a Swedish student in Prague in 1375 have been bound together with materials copied at Vadstena at about the same time or shortly after.

The fifteen so-called collationes are numbered (collacio prima, secunda etc), and, with a few exceptions, it is indicated on what occasions they were delivered or intended for delivery. The series takes its beginning with the twenty-third Sunday after Trinity, which in the year 137616 November, and extends at least to 19 January 1377 (number 14). For items 11, 12 and 15 there is no indication of a preaching occasion. However, a closer examination of the scriptural themes for the sermons can give us further clues as to how these gaps should be filled. Collatio 1 (henceforth $\mathrm{C} 1 \mathrm{etc}$ ) uses a text derived from the Gospel of the day, i.e. the 23rd, 24th etc. elsewhere Sunday after Trinity (Matthew 22. 15-20). In C2 and $\mathrm{C} 3$ the text is from the Gospel reading, in C4-C6 from the Epistle, in C7C10 from the Gospel, and in C14 from the Epistle, not the Epistle for the feast of St Henricus as in the rubric, but for the second Sunday after Epiphany. Thus we arrive at a clearly discernable pattern for this series of collationes: their themes are taken either from the Gospel or the Epistle of the days of the liturgical year indicated in the rubrics. If we assume that this is the case also for the remaining non-rubricated collationes, we would be able to decide for what occasions these were composed. In C11 and C12 the themes are extracted from the Gospel of the second Sunday after Epiphany, in C13 from the Epistle of the first Sunday

\footnotetext{
Samlingar och studier till svenska kyrkans historia, 18. Ed. by Hilding Pleijel (Stockholm: Svenska kyrkans diakonistyrelses bokförlag, 1948), pp. 107-09. The collationes are frequently quoted by C.G. Andrén in his study of the Sacrament of Confirmation published in 1957, and in the introduction to his edition of the treatise De septem sacramentis, published in 1963. See Carl-Gustaf Andrén, Konfirmationen i Sverige under medeltid och reformationstid. Bibliotheca Theologiae Practicae, 1 (Lund: Gleerup, 1957), pp. 44-45 and elsewhere, and De Septem Sacramentis. En sakramentsutläggning frain Vadstena kloster. Bibliotheca Theologiae Practicae, 15 (Lund: Gleerup, 1963), p. 60. They are also used by B. I. Kilström in his important book on the catechetical education of the laity. See Bengt Ingmar Kilström, Den kateketiska undervisningen i Sverige under medeltiden. Bibliotheca Theologiae Practicae, 8 (Lund: Gleerup, 1958), pp. 196, 272-73. The book historian T. Kleberg refers to them briefly in his remarkably detailed study of medieval libraries in Uppsala as does also H. Roelvink in his examination of medieval Swedish Franciscans. See Tönnes Kleberg, Medeltida Uppsalabibliotek. II. Bidrag till deras historia fram till àr 1389. Acta Universitatis Upsaliensis. Skrifter rörande Uppsala universitet. C. Organisation och historia, 25 (Uppsala: Uppsala universitet, 1972), pp. 76-77, 117 and Henrik Roelvink, Franciscans in Sweden. Medieval Remnants of Franciscan Activities. Scripta Franciscana (Aassen: Van Gorcum, 1998), pp. 142, 149. A. Härdelin, the leading Swedish scholar in the field of medieval sprituality discusses the collationes in two works, in more detail in the latter. See Alf Härdelin, Kult, kultur och kontemplation. Studier i medeltida svenskt kyrkoliv (Skellefteå: Artos, 1998), pp. 206-07, and Världen som yta och fönster. Spiritualitet $i$ medeltidens Sverige. Runica et Mediævalia. Scripta minora, 13 (Stockholm: Sällskapet Runica et Mediævalia, 2005), pp. 235, 244 and elsewhere.
} 
after Epiphany, and in C15 from the Gospel of Septuagesima Sunday. The odd one out in this series is C13 which is linked to the first Sunday after Epiphany but in the manuscript is copied after C11-12 with themes from the following Sunday. It is possible that the scribe copied the sermons in the wrong order by mistake, and that C13 should have followed immediately after C10. Another peculiarity in relation to the liturgical year is that in 1376 the 25th Sunday after Trinity coincided with the first Sunday in Advent (30 November), and that in 1377 the second Sunday after Epiphany coincided with Septuagesima Sunday (25 January). This means that C4 was meant to be preached on the same day as C5-6, and that C13 was meant to be preached on the same day as C15. If we sum up, Ingemar intended his fifteen collationes for use in the period extending from 16 November 1376 until 25 January 1377 with the exception of the period from Christmas until Epiphany and with a few minor disruptions of the chronological order between the sermons.

Immediately following these collationes are copied three more sermons by Ingemar: one intended for the synod in Uppsala in 1376 ('In synodo Vpsalensi anno Christi 1376', fols 40r-43r); one for the meeting of the counsellors of the realm in Södertälje in 1377 ('Sermo fratris Ingemari in consilio dominorum in Telghis anno Christi 1377', fols 43r-45v), and finally a sermon on the theme 'Gaudete in Domino' (Philippians 4. 4, fols 45v-46r). The latter biblical quote is taken from the Epistle reading for the fourth Sunday in Advent. From other sources we know that the Uppsala synod in 1376 was celebrated on 1 July, and that the meeting of the counsellors in Södertälje took place the first few days of June $1377 .{ }^{4}$ For an overview of the fifteen collationes see the following table.

\begin{tabular}{|c|c|l|l|}
\hline Collatio & \multicolumn{1}{|c|}{ Fol. } & \multicolumn{1}{|c|}{ Occasion } & \multicolumn{1}{c|}{ Theme } \\
\hline 1 & 26r-v & $\begin{array}{l}\text { 23rd Sunday after Trinity } \\
\text { Rubr.: Dominica 23 } \\
\text { In marg.: Collacio prima }\end{array}$ & $\begin{array}{l}\text { Est ymago hec et superscripcio } \\
\text { Cesaris (Matthew 22. 20) }\end{array}$ \\
\hline 2 & 26r-27r & $\begin{array}{l}\text { 24th Sunday after Trinity } \\
\text { Rubr.: Dominica 24 post trini- } \\
\text { tatem } \\
\text { In marg.: 2a collacio }\end{array}$ & $\begin{array}{l}\text { Princeps vnus accessit } \\
\text { (Matthew 9. 18) }\end{array}$ \\
\hline 3 & $27 \mathrm{r}-\mathrm{v}$ & $\begin{array}{l}\text { 24th Sunday after Trinity } \\
\text { Rubr.: De eadem dominica col- } \\
\text { lacio } \\
\text { In marg.: Collacio 3a }\end{array}$ & $\begin{array}{l}\text { Impone manum tuam super eam } \\
\text { (Matthew 9. 18) }\end{array}$ \\
\hline
\end{tabular}

4 Diplomatarium Suecanum, vol. I- (Stockholm: Riksarkivet, 1829-), vol. XI:1 (2006), no 9246, vol. XI:2 (2009), nos 9510, 9512-15. 


\begin{tabular}{|c|c|c|c|}
\hline 4 & $27 v-28 r$ & $\begin{array}{l}\text { 25th Sunday after Trinity } \\
\text { Rubr.: Dominica } 25 \text { collacio } \\
\text { In marg.: Collacio } 4 \mathrm{a}\end{array}$ & $\begin{array}{l}\text { Ecce dies veniunt } \\
\text { (Jeremiah 23.5) }\end{array}$ \\
\hline Collatio & Fol & Occasion & Theme \\
\hline 5 & $28 r-29 r$ & $\begin{array}{l}1 \text { Advent } \\
\text { Rubr.: Dominica prima aduen- } \\
\text { tus collacio } \\
\text { In marg.: Collacio } 5 \mathrm{a} \\
\end{array}$ & $\begin{array}{l}\text { In die honeste ambulemus } \\
\text { (Romans 13.13) }\end{array}$ \\
\hline 6 & $29 r-30 r$ & $\begin{array}{l}1 \text { Advent } \\
\text { Rubr.: De eadem dominica col- } \\
\text { lacio } \\
\text { In marg.: Collacio 6a } \\
\end{array}$ & $\begin{array}{l}\text { Induamur arma lucis } \\
\text { (Romans 13.12) }\end{array}$ \\
\hline 7 & $30 r-v$ & $\begin{array}{l}2 \text { Advent } \\
\text { Rubr:: Dominica secunda a- } \\
\text { duentus } \\
\text { In marg.: Collacio } 7 \mathrm{a}\end{array}$ & $\begin{array}{l}\text { Arbores producunt ex se fructum } \\
\text { (Luke } 21.30)\end{array}$ \\
\hline 8 & $31 r-32 r$ & $\begin{array}{l}2 \text { Advent } \\
\text { Rubr.: De eadem dominica col- } \\
\text { lacio } \\
\text { In marg.: Collacio } 8 \mathrm{a}\end{array}$ & $\begin{array}{l}\text { Respicite et leuate capita vestra } \\
\text { (Luke 21. 28) }\end{array}$ \\
\hline 9 & $32 r-33 r$ & $\begin{array}{l}3 \text { Advent } \\
\text { Rubr.: Dominica tercia aduen- } \\
\text { tus } \\
\text { In marg.: Collacio 9a } \\
\end{array}$ & $\begin{array}{l}\text { Mortui resurgunt } \\
\text { (Matthew 11.5) }\end{array}$ \\
\hline 10 & $33 r-34 r$ & $\begin{array}{l}3 \text { Advent } \\
\text { Rubr.: Item de eadem dominica } \\
\text { collacio } \\
\text { In marg.: Collacio } 10 \mathrm{a} \\
\end{array}$ & $\begin{array}{l}\text { Ecce mitto angelum meum } \\
\text { (Matthew 11.10) }\end{array}$ \\
\hline 11 & $34 r-35 v$ & $\begin{array}{l}\text { 2nd Sunday after Epiphany } \\
\text { In marg: Collacio 11a }\end{array}$ & \begin{tabular}{|l} 
Haurite nunc \\
$($ John 2.8)
\end{tabular} \\
\hline 12 & $35 v-36 v$ & $\begin{array}{l}\text { 2nd Sunday after Epiphany } \\
\text { In marg.: Collacio } 12\end{array}$ & $\begin{array}{l}\text { Hoc fecit Ihesus } \\
\text { (John 2.11) }\end{array}$ \\
\hline 13 & $36 v-38 r$ & $\begin{array}{l}\text { 1st Sunday after Epiphany } \\
\text { In marg.: Collacio } 13 \mathrm{a} \\
\end{array}$ & $\begin{array}{l}\text { Probetis que sit voluntas Dei } \\
\text { (Romans 12.2) }\end{array}$ \\
\hline 14 & $38 r-39 r$ & $\begin{array}{l}\text { St Henricus (19 January) } \\
\text { Rubr.: De sancto henrico } \\
\text { In marg.: Collacio } 14 \mathrm{a} \\
\end{array}$ & $\begin{array}{l}\text { Docet in doctrina } \\
\text { (Romans 12.7) }\end{array}$ \\
\hline 15 & $39 r-40 r$ & $\begin{array}{l}\text { Septuagesima Sunday } \\
\text { In marg.: Collacio } 15\end{array}$ & $\begin{array}{l}\text { Sic erunt nouissimi primi } \\
\text { (Matthew 20.16) }\end{array}$ \\
\hline
\end{tabular}

It was normal practise that episcopal visitations took place during the winter, ${ }^{5}$

5 Göran Inger, Das kirchliche Visitationsinstitut im mittelalterlichen Schweden. Bibliotheca 
but no visitation journey undertaken in the winter of 1376-77 by Archbishop Birger is known from other sources. In fact we know very little about his whereabouts during this winter. Only three records have been preserved that can inform us further, and thus help us to set the scene of the delivery of the collationes. On 27 October 1376 he issued a charter in Vårdsätra just south of Uppsala; on 9 December 1376 he attended a meeting in the Franciscan house in Stockholm and on 25 January 1377 he was present in Uppsala to confirm a sale of land to the cathedral. ${ }^{6}$ The fact that he was in Stockholm only two days after the second Sunday in Advent (which was 7 December), is a clear indication of that his visitation was in fact not a journey extended over a considerable period of time into the different parts of the diocese. Instead it must have taken place in the proximity of Uppsala. On 25 January he was back in that town, so the last sermon by Ingemar in connection with this visitation was probably given there.

The identity of Ingemar remains enigmatic. Although the manuscript was both written in Vadstena abbey and kept in the library of that convent, Aarno Maliniemi points out that no 'frater Ingemarus' is mentioned in any of the sources connected to Vadstena and that he therefore cannot be assumed to have been a Birgittine priest brother, regardless of how famous these were for their assiduous preaching. ${ }^{7}$ Carl-Gustaf Andrén believes that he had some connection with the diocese of Uppsala, and that his function may have been to accompany and assist the archbishop. ${ }^{8}$ Alf Härdelin believes that Ingemar was a mendicant friar who had been enrolled to preach on these particular occasions, possibly a Franciscan from Uppsala or a Dominican from Sigtuna. ${ }^{9}$ The suggestion is definitely worth considering since it is well known that English bishops could enrol mendicant friars to preach in connection with their visitations, ${ }^{10}$ and Henrik Roelvink points out that the contacts between the chapter at Uppsala and the friars "were so good that a friar minor could very well have been granted the honour of preaching on solemn occasions". ${ }^{11}$ In any case, it turns out to be extremely difficult to find

Theologiae Practicae, 11 (Lund: Gleerup, 1961), p. 412: 'Im allgemeinen unternahmen die schwedischen Bischöfe ihre Visitationsreisen im Bistum im Winter, und zwar kurz vor Weihnachten oder während der ersten Monate des Jahres.'

6 Diplomatarium Suecanum, XI:1 (2006), nos 9348, 9378 and XI:2 (2009), no 9509.

7 Maliniemi, De S. Henrico, pp. 21-22; in addition, no person by that name is recorded in the Memorial Book of Vadstena abbey. See Claes Gejrot, Diarium Vadstenense. The Memorial Book of Vadstena Abbey. A Critical Edition with an Introduction. Studia Latina Stockholmiensia, XXXIII, (Stockholm: Stockholm University, 1988).

8 Andrén, Konfirmationen, pp. 44-45 note 48.

9 Härdelin, Kult, kultur och kontemplation, p. 206; Härdelin, Världen som yta och fönster, pp. $235,442$.

10 See Siegfried Wenzel, Latin Sermon Collections from Later Medieval England. Orthodox Preaching in the Age of Wyclif (Cambridge: Cambridge University Press, 2005), p. 289 note 10.

11 Roelvink, Franciscans in Sweden, p. 149. 
any plausible candidates in the extant contemporary charters or in other relevant source material. A couple of names have been mentioned in the studies just quoted, but these attempts are little more than educated guess-work.

Seemingly, these short sermons on the Seven Sacraments appear to fit in well with what we know about visitation sermons in general. A statute for the diocese of Strängnäs (adjacent to the diocese of Uppsala) from 1480 states that the preacher ('habiturus sermonem') at Episcopal visitations should treat:

'... things pertaining to the observation of the Sacraments, confessions being made before priests, the satisfaction of prescribed penance, tithes, offerings $[\ldots]$ and all other things that belong to the salvation of the souls. ${ }^{12}$

This statute is a century younger than the collations in MS C 5, but there is no reason to believe that similar regulations did not also apply at the end of the fourteenth century. From English sources we learn that the word collatio is sometimes used in connection with visitation sermons. A Franciscan preacher, probably named Nicholaus Philip, from the first half of the fifteenth century, remarks in one of his own visitation sermons that the visitator usually preaches 'per modum collacionis'. ${ }^{13}$ The most plausible interpretation of statutes like the one from Strängnäs just quoted is probably that the envisaged visitation sermon was targeted at two categories of listeners, either at only one of them exclusively, or at both of them simultaneously. On the one hand it was the vehicle for the bishop to convey instruction to his clergy about the Sacraments, confession, tithes and such things. On the other hand, it was aimed at all who were present in the church. We remember that secular priests throughout the country, according to stipulations in a host of contemporary statutes should instruct their parishioners about things similar to the pieces just mentioned, besides the Ten Commandments, Our Father, Hail Mary and other things belonging to the fundamen-

12 'Qui in huiusmodi sermone inter cetera tangat ea, que ad ecclesie sacramenta pertinent observanda, de confessionibus propriis sacerdotibus faciendis, de penitenciis iniunctis fideliter et effectualiter persoluendis, de decimis et oblacionibus faciendis et alia [...] que ad salutem pertinent animarum'. Jaakko Gummerus (ed.), Synodalstatuter och andra kyrkorättsliga aktstycken frän den svenska medeltidskyrkan. Skrifter utgifna av Kyrkohistoriska föreningen, II:2 (Stockholm: Norstedt \& Söner, 1902), p. 94.

13 Quoted from G. R. Owst, Preaching in Medieval England. An Introduction to Sermon Manuscripts of the Period 1350-1450 (Cambridge: Cambridge University Press, 1926), p. 150. On this manuscript and its author see also Wenzel, Latin Sermon Collections, pp. 95-99. On the meaning of collatio see also most recently Siegfried Wenzel's study 'A Note on Collatio in LateMedieval Preaching', Swedish Students at the University of Vienna in the Middle Ages, ed. by Olle Ferm and Erika Kihlman. Runica et Mediavalia. Scripta minora, 20 (Stockholm: Sällshapet Runica et Mediaevalia, 2011), pp. 235-43. 
tals of catechetical instruction. ${ }^{14}$ However, we have every reason to believe that the hand-written remains of a bishop's instructions to the priests of his diocese, even if communicated by an assistant preacher, are clearly discernable from the instruction about catechetical elementa directed to the laity, most prominently through the language they are in. The priests could be addressed in Latin, and probably they normally were, at least on solemn occasions such as visitations, while the ordinary church-goer certainly expected to be spoken to in a language he or she could understand.

So, how should we describe the collationes by Brother Ingemar? We can not dispute that they are written in Latin, but one of the things that recent scholarship on medieval sermons has taught us is that the language in which a sermon is recorded is not necessarily the same as the one in which it was or was meant to be delivered. ${ }^{15}$ So, the mere fact that these sermons are recorded in Latin does not imply that they were also preached in that language. The questions of audience and performance have always been of crucial importance in medieval sermon studies, and remain so within the current development of the field, and many sermonists have endeavoured to determine by whom sermon collections or individual sermons have been produced, and for what different categories of listeners or readers they may have been intended. ${ }^{16}$ From a strictly formal point of view all of them are organized according to the 'modern' 'thematic' or 'scholastic' method, that is using thema, antethema or prothema, reiteration and division of the theme and subsequent development under the different principalia generated by the division. This structure, however, does not imply that the sermons were also directed to a learned audience, or to an audience of clerics. For one thing, we cannot know for sure if the preacher really communicated such elaborate divi-

14 For such regulations see Sven-Erik Pernler, 'Predikan ad populum under svensk medeltid', Predikohistoriska perspektiv. Studier tillägnade Åke Andrén. Ed. by Alf Härdelin (Stockholm: Verbum, 1982), pp. 73-94. For the question of the expected level of knowledge among the laity see Norman Tanner and Sethina Watson, 'Least of the laity. The minimum requirements for a medieval Christian', Journal of Medieval History, 32 (2006), pp. 395-423.

15 Wenzel, Latin Sermon Collections, pp. 9-10; but see also for example Jean Longère, La prédication médiévale (Paris: Études augustiniennes, 1983), p. 164; Beverly Maine Kienzle, 'Conclusion', The Sermon. Typologie des sources du moyen âge occidentale, 81-83 (Turnhout: Brepols, 2000), pp. 971-74; for the Vadstena sermon see Andersson and Borgehammar, 'The Preaching', p. 216 and Roger Andersson, De birgittinska ordensprästerna som traditionsförmedlare och folkfostrare. Runica et Mediævalia. Scripta minora, 4 (Stockholm: Sällskapet Runica et Mediævalia, 2001), pp. 13, 22-24.

16 In a recent study I have tried to identify a few systematic differences between the academic university sermon and the popular sermon in the Vadstena tradition. See Roger Andersson, 'Popular and Academic Preaching on Good Friday. A Comparative Study', Swedish Studentes at the University of Vienna in the Middle Ages (see note 13), pp. 175-233. See also for example Alan J. Fletcher, Late Medieval Popular Preaching in Britain and Ireland. Sermo, 5 (Turnhout: Brepols, 2009) and Holly Johnson, The Grammar of Good Friday. Macaronic Sermons of Late-Medieval England, Sermo, 8 (Turnhout: Brepols, 2011). 
sions or distinctions in his oral delivery. And for another, rather the opposite view it may seem, but with the same result, distinctions and structured schemes may have served primarily as mnemonic aids ${ }^{17}$ and do not necessarily testify to the degree of the 'learnedness' of the preacher, of the audience, or of the structure itself. Instead, we will here see how the Sacraments are introduced and identified. Are they made subject to a more qualified theological interpretation or explanation? Does the preacher give advice as to how they should be properly administered? Or is he, on the other hand, trying to persuade the audience about their indispensability, to infuse in them a sense of longing for their salvific powers? ${ }^{18}$ Does he, in short, strive to make the listener favourably disposed to the Sacraments, instead of explaining their theological signification in detail? If so, it would be natural to view these collations as examples of preaching coram populo rather that preaching coram clero. Of the scholars previously mentioned, Bengt Ingmar Kilström seems inclined to believe that the former of these assumptions is correct:

'The collationes by frater Ingemarus are excellent examples of how the popular instruction about the Sacraments could be shaped'19

Alf Härdelin, on the other hand, takes the opposite position:

'And as a result of their relatively high intellectual level the collationes by Brother Ingemarus give on the whole the impression of being directed to the priests assembled at the visitations, rather than of being intended for the ordinary people. ${ }^{20}$

I will now give brief summaries of the main contents of the fifteen collationes (C1-C15) with the exception of C8, which will be reviewed more in detail below, and $\mathrm{C} 14$ which does not discuss the Sacraments. ${ }^{21}$

17 See for example Kirsten M. Berg, 'On the Use of Mnemonic Schemes in Sermon Composition', Constructing the Medieval Sermon. Sermo, 6. Ed. by Roger Andersson (Turnhout: Brepols, 2008), pp. 221-36 and, most recently, Kimberly A. Rivers, Preaching the Memory of Virtue and Vice. Memory, Images, and Preaching in the Late Middle Ages. Sermo, 4 (Turnhout: Brepols, 2010).

18 This 'participatory' perspective of lay people taking active part in the liturgical celebrations is prevalent in Eamon Duffy's classical study The Stripping of the Altars. Traditional religion in England, c.1400-c.1580 (Updated edn, New Haven, Conn.: Yale University Press, 2005). Johnson, The Grammar of Good Friday, underlines the importance of the reciprocal process of emotional appeal from the part of the preacher and emotional response from the part of the listeners for the succesful delivery of a sermon in a liturgical setting.

19 Kilström, Den kateketiska undervisningen, p. 273 (my translation): 'Frater Ingemarus' collationes ge utmärkta prov på hur den folkliga undervisningen om sakramenten kunnat utgestaltas.'

20 Härdelin, Kult, kultur och kontemplation, p. 207 (my translation): 'Och Broder Ingemars collaciones ger genom sin relativt höga intellektuella nivå på det hela taget ett intryck av att vara riktade snarare till de präster som mött upp till visitationerna än till den vanliga allmogen.'

21 These short summaries are based on preliminary transcriptions made by Josef Redfors for 
C1. 'Whose image and inscription is this?' (Matthew 22. 20). Three images are more precious than stones, and these three correspond to three Sacraments: the image of a man (Baptism), the image of a lion (Confirmation), and the image of an eagle (Extreme Unction). Further, temporal laws are written in a volume with a capital letter depicting the moon, whereas the eternal laws are written in another volume with a capital letter depicting the sun. This is the Sacrament of Holy Eucharist. Finally, the Sacrament of Penance is compared to the creative work of a sculptor. The cutting out of the superfluous wood or stone is contrition, the formation of the members is confession, the whitewashing or plastering is fasting, and the decoration with colours and gold is almsgiving.

C2. 'A certain ruler came up' (Matthew 9. 18). A good ruler should first and foremost ordain good laws. In the Sacrament of Baptism he ordained the law in the young, to encourage chastity, in the Holy Eucharist he ordained the feast of sobriety against gluttony, in Penance he ordained the law of truth against the treachery of merchants, and in Matrimony he ordained love of charity against blind voluptuousness. A good ruler should also unite his people in mutual love, and therefore God must unite us in the Sacrament of Confirmation, so that we are not conquered by the world, the flesh or the devil. Finally, a good ruler should teach good habits to his advisors, which, spiritually speaking, corresponds to the Sacrament of Orders.

C3. 'Lay thy hand upon her' (Matthew 9. 18). The imposition of the divine hand must precede the medical treatment of the longing soul. The hand has several significations in relation to the Sacraments: in Baptism it is the sign of fidelity, in Confirmation the sign of peace, in Penance the sign of sanity, in Holy Eucharist the sign of love, and in Extreme Unction the sign of necessity.

C4. 'Behold the days come' (Jeremiah 23. 5). Before the Advent of Christ, the world will be filled by the darkness of night on every side. But 'light is risen' as is spoken by Isaiah (9.2), and the sanctified days have shone on us, days, namely, in which what is obscure is illuminated (Baptism), the cold is made warm (Confirmation), the sick are strengthened (Penance), the florid is brought to life by the sun (Holy Eucharist), and the harmful is brought to rest (Extreme Unction).

C5. 'Let us walk honestly, as in the day' (Romans 13. 13). By the Seven Sacraments God works our salvation and these Sacraments are the first seven days of Creation. Baptism is the first day when God created heaven, earth and light. Confirmation is the second day when God made the firmament of Heaven con-

the project The Preaching of the Vadstena Brothers (Vadstenabrödernas predikan) which was carried out at Uppsala University in 1994-97. These transciptions are available at the Department of Linguistics and Philology at Uppsala University. The names of the Sacraments used in this article are in accordance with the online edition of The Catholic Encyclopedia (http://www.newadvent.org/ cathen), s.v. 'Sacraments', that is Baptism, Confirmation, Holy Eucharist, Penance (and Reconciliation), Extreme Unction, Orders and Matrimony. 
taining seven stars. Penitence is the third day when God produced herbs, trees and every kind of fruit. Men are trees who produce sap (tears) from contrition, leaves (words) in confession, and fruits of satisfaction. Holy Eucharist is the fourth day in which God made two great lights: the moon and the sun. Orders is the fifth day when God created the fishes of the sea and the fowls of the air, because clerics are both like fish (humid and frigid) and like birds (warm and dry). Matrimony is the sixth day when God created the beasts of the earth, because some married people live like beasts. Extreme Unction is the seventh day, the day when God rested from all work.

C6. 'Let us put on the armour of light' (Romans 13. 12). The armour of light is the virtues, and man can be clad in virtues for different reasons: usefulness, security and pleasure. In the same way some Sacraments cover man for the reason of usefulness (Baptism, Extreme Unction), some arm man for the reason of security (Confirmation, Penance), and some decorate man for the reason of pleasure and benevolence (causa iocunditatis; Holy Eucharist, Orders, Matrimony).

C 7. 'The trees now shoot forth their fruit' (Luke 21.30). In order to be fruitful different trees need to be treated in different ways, ways that correspond to the Sacraments: old trees need to be cleansed (Baptism, Penance), young trees need to be transplanted (Confirmation, Holy Eucharist, Orders, Extreme Unction), and twigs need to be grafted on the tree (Matrimony).

C8. See in more detail below.

C9. 'The dead rise again' (Matthew 11. 5). There are many ways in which man is killed by his sin, and equally many ways in which he is raised by means of the Sacraments. Now death can strike man in his own house in different ways, with different Sacraments as remedies. He can be killed by a traitor while sleeping in his bed (Baptism, Confirmation, Penance), he can die from hunger (Holy Eucharist), he can be slaughtered with a sword (Orders), he can die from cold (Matrimony), and he can simply be poisoned (Extreme Unction).

C10. 'Behold I send my angel' (Matthew 11. 10). The angel is said to have been sent for different reasons. For consolation of man (Baptism), to teach us the distinction between the good and the evil (Confirmation), to enlighten man (Penance), to comfort man (Holy Eucharist), to praise man (Orders), to preserve man in the good state (Matrimony), and to defend man from the devil (Extreme Unction).

C11. 'Draw out now' (John 2. 8). This word is related to the prophecy of Isaiah: 'You shall draw waters with joy out of the Saviour's fountains' (Isaiah 12. 3). Now, the Saviour's fountains are the Sacraments of the Church. Baptism contains bright and clear water, Confirmation contains thin and smooth water, Penance contains sweet water, Holy Eucharist contains living water, Orders contains humid and moist water, Matrimony contains cold water and Extreme Unction contains healing water. 
C12. 'This did Jesus.' (John 2. 11). Christ works all things in us, and we have everything in Christ. If you are sick he is the physician (Baptism), if you need help he is the power and virtue (Confirmation), if you are oppressed by unrighteousness he is merciful (Penance), if you are hungry he is the food (Holy Eucharist), if you want to be just and fair he is the justice (Orders and Matrimony), if you long for Heaven he is the way (Extreme Unction).

C13. 'That you may prove what is the will of God.' (Romans 12. 2). The will of God is hidden but is shown by signs in the Sacraments. In Baptism, God's will is to purify us. The gravity of water can be decided by using cloths of the same weight. In Confirmation, God's will is to give us a healthy treatment. Pure balsam has the capacity of making wounds solid and of reinforcing (confirming) the solid. In Penance, God's will is to give us indulgence from depravity. This is proved by the way a pelican giving birth in the sign of Gemini can tell the thoughts of a crying man if a mirror is placed before its eye. In Holy Eucharist, God's will is to give us a proof of his love. Thus, the will of God is shown in us when we wear the garments of good works, and when our smell is that of devotion. In Orders, God's will is to give us dignity. There is a certain stone, whose clarity reveals that God is pleased, and whose obscurity reveals that God is provoked. In Matrimony, God's will is to give us the pleasures of chastity. Pure silver is not destroyed in the fire, but remains bright and solid. Silver is Matrimony, and fire is tribulation which should never be allowed to ruin Matrimony. In Extreme Unction, God's will is to give us sufficient sanity. If you pour water in oil which is not boiled, it remains silent, but if the oil is boiling it makes a big noise. The oil is devotion, the water is the forgiving of sins, and the noise is praising of God (fragor Dei collaudacio).

C14. A sermon for St Henricus which does not treat the Sacraments.

C15. 'So shall the last be first' (Matthew 20.16). God wants man to stay in his place for the reason of humility. As a wife in her house (Baptism, Matrimony), as a king in his kingdom (Confirmation, Extreme Unction), as a duke in the battle (Penance), and as a guest visiting for lunch (Holy Eucharist).

From these short summaries it is hardly possible to get anything more than a very preliminary idea about the contents of the sermons. It is possible to agree with Andrén when he says that the sermons often 'offer a theological interpretation of the liturgical use connected to the Sacraments'. ${ }^{22}$ But the same scholar also remarks that medieval theologians often try to describe the effect on man of the Sacraments by using 'different images', and quotes from Brother Ingemar to prove his point. ${ }^{23}$ And we see many examples of such imagery in the brief sum-

22 'De starkt allegoriserande utläggningarna [...] ger [...] ofta en teologisk tolkning till de liturgiska bruken i samband med sakramenten.' Andrén, Konfirmationen, pp. 44-45 (my translation).

23 'I olika bilder har man också sökt klargöra deras verkan i människan'. Andrén, Konfirmationen, p. 56. 
maries above. In using the concept of similitude, the preacher can more easily visualize the abstract categories and open up the heart of the listeners for the meaning of the Sacraments in relation to their own salvation. In fact, the everlasting impression of these collationes is that this rhetorical and 'emotional' approach to the Sacraments is prevailing and more immediately striking than their didactic purpose. Some exempla taken from the realms of magic and astrology, such as those about the pelican or the precious stone in C13, may appeal to more popular notions and beliefs.

I will give a more detailed account of one of the sermons (C8) to make these points more clear.

Look up, and lift up your heads! (Luke 21. 28).

Two things prevent man from looking upwards and seeing Heaven, which is blindness and crookedness. Blindness deprives man of his sight, and crookedness makes him lean downwards. Before the incarnation of Christ mankind was blinded, and this can be explained by means of a similitude. There is a natural hostility between the raven and the deer. When a raven wants to kill a deer it fills its wings with dust, places itself between the horns of the deer, and sprinkles the dust in the deer's eyes. And so the blinded animal walks about by rough ways, eventually falls and is soon devoured by the raven. Spiritually this is what the devil does, when he blinds man by the dust of filthy sin, and eventually devours him. But Christ intercedes and institutes the Sacrament of Baptism, whereby light is brought back to the blinded.

As regards the other Sacraments, we should know that many things may cause the lowering of the head, such as apathy, pain (sorrow), shame, fear and horror.

Apathy is a feebleness of the head which is the result of either heat or cold. It can be caused by heat as when a man turns frantic. This illness may cause him to run to the water to submerge there, to the fire to succumb there or to a steep abyss to throw himself down there. The remedy for this dangerous heat is the oil of roses which has the capacity of chilling off the head. The oil of roses should be understood as the oil used in the Sacrament of Confirmation. It is prepared of the rose, which is Christ, with armed power, and has the capacity to press back any immoderate heat.

Cold causes not only the illness of the head, but also the illness of the body, and this results in the torpidity of weariness. The remedy is an herb known as Abronatum (Southernwood or Lad's Love), which, according to the experts, can settle the pain of the head when it is boiled in water. This medicine is the Sacrament of Penance. The water is contrition, the fresh herb is confession, and the fire that makes the water boil with love is satisfaction.

Also sorrow can cause the depression of the head. Now, what pain is bigger than when someone is separated from a dear friend? As when Jacob lost his son, and tore his garments as a sign of sorrow (Gen. 37. 34). Be how it may; an even 
greater sorrow, indeed the greatest of them all, is when friends are separated, such as when man and God are separated by sin. If someone meets a friend in Christly love, invites him and then allows him to dine with him, a great joy normally follows and the heads are raised. This is exactly what our friend the Son of God does in the Sacrament of Holy Eucharist. Through his grace he brings us back to the original friendship and restores us with his holy body.

Fear can cause the inclination of the head. If a servant abandoned his lord and became attached to another, wouldn't he, in the case he happened to meet his first master, be struck by fear and lower his head? If, however, his lord did not only receive him with love, but also forgave him his offence, the servant would certainly erect his head. God does the same to his spiritual servants. No matter how often they act against the Sacrament of Orders, God receives them out of his goodness and confides to them the entrusted talent.

Sometimes inclination of the head is caused by shame. Like when someone is unrighteously accused and, as if he were not worthy to answer those who are better, lowers his head and exhibits his shame in his face. Through the Sacrament of Matrimony, however, a noble man can bring about that he, just as the legitimate Son of God, will not have to be ashamed, but rather will be glorified by nobility.

Sometimes it is caused by horror. In a war, a man fears much for his head. And in order to avoid a lethal stroke, he inclines his head. Spiritually, at the very end of life, the devil fights vigorously against man. He strives to give him a blow of hopelessness in his head and therefore God protects his head with the oil used in the Sacrament of Extreme Unction, in order that he is not injured by the enemy.

The allegory of the raven and the deer, and the much diversified imagery connected to each of the Seven Sacraments (for example the oil of roses or the herb Lad's Love) and evoking different reasons for a man to decline his head, are used here by the preacher as a point of departure to arrive at his main goal, which is to persuade the listener about the salvific powers of the Sacraments, and to make him long for them, since they have to do with the salvation of his own soul. It must be said to be a very successful strategy. However, at least as far as I can understand, very little in the sermon seems to be directed exclusively to the clergy, such as could be concrete recommendations about the administration of the Sacraments. Instead, the overall impression is that Ingemar wants his audience to identify more with the poor servant occurring in the passage treating the Sacrament of Orders than with those for which this Sacrament is conceived. Or, for that matter, more with the terrified warrior seeking to protect his head than with those whose obligation it is to administer the Extreme Unction. Therefore, I am inclined to regard the collationes pronounced by Ingemar as directed to a much broader variety of listeners than exclusively to the priests, probably comprising all who were present in the churches visited by the archbishop, including 
the priests (needless to say), but perhaps targeted specifically at lay people. This was an audience that needed not only instruction about the Seven Sacraments, but also needed to be moved in their hearts to fully grasp their effects. 